\title{
Sistem Informasi Geografis Balitbang Agama Semarang Berbasis Web
}

\author{
${ }^{1 *}$ Rifqi Misbahul Arif, ${ }^{2}$ Moch.Subchan Mauluddin \\ ${ }^{1,2}$ Jurusan Teknik Informatika, Fakultas Teknik, Universitas Wahid Hasyim \\ Jl. Menoreh Tengah X/22, Sampangan, Semarang 50236, \\ *Email : rifmisarif22@gmail.com
}

\begin{abstract}
Abstrak
Peneltian dilakukan di UPT Balitbang Agama Semarang di bawah pengawasan Kemenag Jawa Jengah, permasalahannya tidak adanya informasi pemetaan sekolah secara digital untuk masyarakat luas dan pendataan sekolah masih konvensional. Penelitian ini bertujuan untuk membangun suatu sistem informasi geografis berbasis web disebut juga (WebGIS) sehingga dapat memberikan informasi yang berguna mengenai lokasi sekolah yang ada di bawah naungan balitbang agama semarang serta mempermudah admin mengelola pendataan sekolah untuk mencapai hasil yang lebih baik dan efisien. WebGIS ini dirancang menggunakan bahasa pemograman PHP dan basis data MySQL sedangkan metode pengembangan sistem ini menggunakan waterfall yang terdiri 5 tahapan yaitu, analisis kebutuhan, perancangan, implementasi, pengujian, dan pemeliharaan. Hasil dari penelitian ini yaitu sistem informasi geografis berbasis web (WebGIS) yang dapat diakses bagi masyarakat umum serta memudahkan admin dalam mengelola pendataan sekolah di bawah naungan balitbang agama Semarang.
\end{abstract}

Kata kunci : GIS, sekolah, SIG, sistem informasi, waterfall, webGIS

\section{PENDAHULUAN}

\subsection{Latar Belakang}

Era perkembangan zaman sudah mengalami pembaruan teknologi yang kini sudah beralih dari yang dulu menggunakan pemetaan secara manual sekarang ini menggunakan peta secara digital sehingga lebih mudah dalam mencari lokasi yang akan dituju, kehadiran teknologi ini dimaksudkan untuk mencapai hasil yang lebih baik dan efisien, Perkembangan pemetaan secara digital dalam bidang ini telah meningkat secara drastis. Banyak kegiatan-kegiatan yang dulunya dikerjakan secara manual yang memakan waktu dan tenaga banyak, sekarang bisa dikerjakan dengan digital menggunakan komputer, sehingga pekerjaan tersebut bisa dengan cepat terselesaikan. teknologi pemetaan digital Sistem Informasi Geografis berbasis web (WebGIS) ini semakin lama telah mengalami pembaharuan dan para developer banyak yang mengembangkan sistem ini karena dalam penayangan dan pengolahan data spasial dalam bidang pemetaan cakupanya lebih luas.

Kota Semarang ibukota jawa tengah bisa menjadi acuan bagi kota lain untuk kemajuan dalam bidang teknologi pada berbagai sektor terutama pada sektor pendidikan, Balai Penelitian dan Pengembangan Agama
Semarang dalam pengembangan sistem ini untuk membantu masyarakat dalam memberikan informasi pemetaan sekolah dan profil dari sekolah tersebut, dalam kasus pengembangan sistem ini untuk memberikan penyediaan informasi kepada masyarakat agar lebih mudah untuk mengetahui profil sekolah dan alamat lokasi sekolah tersebut, sistem ini dibuat lebih simple dan user interface yang mudah dipahami agar masyarakat mudah mengaksesnya karena nanti hasil keluaran dari sistem ini berbentuk website yang bisa diakses masyarakat luas.

\subsection{Rumusan Masalah}

Berdasarkan latar belakang di atas maka muncul permasalahan sebagai berikut:

1. Bagaimana membuat sistem informasi geografis pendataan sekolah dibawah naungan balitbang dan dilengkapi profil secara singkat pada studi kasus sekolah di Semarang?

2. Bagaimana cara untuk mempermudah pengguna dikalangan balitbang dan masyarakat luas dalam mencari sekolah di Semarang? 


\subsection{Tujuan Penelitian}

Berdasarkan rumusan masalah di atas tujuan dari penelitian ini adalah sebagai berikut:

1. Membuat sistem informasi geografis untuk pendataan sekolah di semarang dibawah naungan balitbang agama

2. Membuat desain website yang simple dan user friendly supaya user dikalangan balitbang dan masyarakat mudah untuk mengaksesnya

\subsection{Manfaat Penelitian}

Manfaat penelitian yang dapat diambil dari penelitian ini sebagai berikut :

1. Hasil penelitian dapat digunakan untuk mempermudah user atau pengguna untuk melihat lokasi sekolah disemarang

2. Hasil penelitian dapat dijadikan sebagai acuan untuk kota lain dalam melakukan pengembangan WebGIS ini untuk memudahkan pengelolaan database Sekolah Madrasah di Semarang secara efektif dalam format Sistem Informasi Geografis sehingga diperoleh tampilan yang interaktif dan komunikatif seperti peta tematik atau peta garis berdatabase,

\section{TINJAUAN PUSTAKA}

\subsection{Penelitian yang relevan}

Penelitian dilakukan dengan mencari sumber jurnal pada internet dan banyak sumber yang didapat penulis namun masalah pada jurnal tersebut tidak mirip dengan masalah yang akan dihadapi penulis dan karena itu penulis mencoba mencari permasalahn yang hamper sama yang diteliti penulis berikut ini review jurnal yang dirangkum penulis secara singkat :

Penelitian oleh Nur Rizky dkk. (2015) berjudul Aplikasi Sistem Informasi Geografis Berbasis WEB Untuk Persebaran Sekolah Menengah Atas (Studi Kasus : Kota Semarang ). Penelitian ini mengkaji tentang suatu sistem informasi geografis yang mampu membantu dinas pendidikan terkait dalam menyediakan sarana informasi geografis pemetaan Sekolah Menengah Atas bagi masyarakat Kota Semarang. Objek penelitian ini yaitu berupa aplikasi sistem informasi tentang pemetaan persebaran Sekolah Menengah Atas ( SMA) di Kota Semarang, Provinsi Jawa Tengah. Hasil penelitian ini berupa sebuah aplikasi SIG berbasis web yang memberikan kemudahan kepada masyarakat untuk mengakses sekolah sekolah mana saja yang bisa dijadikan referensi untuk melanjutkan pendidikan. Selain itu, aplikasi ini juga bisa digunakan untuk melihat data - data informasi yang terdapat di suatu sekolah sehingga bisa dijadikan suatu referensi informasi yang tentunya akan sangat berguna bagi masyarakat.

Penelitian oleh Kharistiani dkk. (2013) berjudul Sistem Informasi Geografis Pemetaan Potensi SMA/SMK Berbasis WEB ( Studi kasus : Kabupaten Kebumen ). Penelitian ini mengkaji tentang Dinas Pendidikan kabupaten Kebumen yang menangani banyak sekolah tetapi cara pengelolaan belum optimal. Untuk itu Dinas Pendidikan kabupaten Kebumen secara sistematis mengembangkan suatu sistem manajerial yang efektif dan efisien, yaitu dengan Sistem Informasi Geografis Pemetaan Potensi SMA/SMK berbasis web.

Dengan adanya dukungan teknologi SIG yang berbasis web, diharapkan pengguna dapat mengakses melalui media internet, sehingga pendistribusian informasi dapat meluas hingga seluruh nusantara. Hasil dari penelitian ini adalah sebuah aplikasi Sistem Informasi Geografis Pemetaan Potensi SMA/SMK Berbasis Web di kabupaten Kebumen yang dapat memberikan informasi tentang SMA/SMK. Hasil pengujian sistem menunjukkan bahwa sistem informasi ini layak dan dapat dipergunakan. SMA/SMK BERBASIS WEB (Studi Kasus : Kabupaten Kebumen)

Pada jurnal sebelumnya yang membahas tentang sistem informasi geografis di semarang dan kebumen namun itu hanya dibatasi untuk sekolah sma/smk saja sedangkan pada penelitian saya mencakup keseluruhan sekolah misalkan, sd/mi smp/mts dan sma/ma sehingga informasi yang dihasilkan lebih detail dan masyarakat bias lebih puas karena sistem ini bias menampilkan keseluruhan sekolah khususnya di semarang kota

\subsection{Sistem Informasi Geografis}

Pengertian Sistem Informasi Geografis : Menurut Irwansyah (2013:1), sistem informasi geografis (SIG) atau Geographic Information System (GIS) adalah sebuah sistem yang didesain untuk menangkap, menyimpan, memanipulasi, menganalisa, mengatur dan menampilkan seluruh jenis data geografis. menurut Prahasta (2014) mendefinisikan Sistem Informasi Geografis sebagai suatu sistem yang berbasiskan komputer yang digunakan untuk 
menyimpan dan memanipulasi informasiinformasi geografis. Sistem Informasi Geografis dirancang untuk mengumpulkan, menyimpan, dan menganalisis objek-objek dan fenomena dimana lokasi geografis merupakan karakteristik yang penting atau kritis untuk dianalisis. Jika definisi sistem informasi geografis diperhatikan maka, sistem informasi geografis dapat diuraikan menjadi beberapa subsistem berikut:

a) Data Input : Subsistem ini bertugas untuk mengumpulkan, mempersiapkan dan menyimpan data spasial dan artibutnya dari berbagai sumber.

b) Data Output : Subsistem ini menampilkan atau menghasilkan keluaran (termasuk mengekspornya keformat yang dikendaki) seluruh atau sebagian basisdata (spasial) baik dalam bentuk softcopy maupun hardcopy.

c) Data Management : Subsistem ini mengorganisasikan baik data spasial maupun tabel-tabel atribut terkait ke dalam sebuah basisdata sedemikian rupa sehingga mudah dipanggil kembali atau di-retrieve, di update, dan di edit.

d) Data Manipulation dan Analysis : Subsistem ini menentukan informasi yang dapat dihasilkan oleh sistem informasi geografis. Selain itu, subsistem ini juga melakukan manipulasi dan pemodelan data untuk menghasilkan informasi yang diharapkan (Irwansyah, 2013:75-76).

Dari pengertian diatas dapat ditarik kesimpulan bahwa Sistem Informasi Geografis merupakan suatu sistem untuk memasukkan, mengelola (penyimpanan dan pemanggilan data), manipulasi dan analisis, serta menyajikan informasi secara geografis berikut dengan deskripsi dari keadaan geografis suatu wilayah untuk digunakan sebagai bahan pengambilan keputusan. (Irwansyah, 2013:75)

\subsection{Sekilas Tentang www Atau Web}

Www atau World Wide Web maupun Web adalah sebuah sistem yang saling terkait dalam sebuah dokumen berformat hypertext yang berisi beragam informasi, baik tulisan, gambar, suara, video, dan informasi multimedia lainnya dan dapat diakses melalui sebuah perangkat yang disebut web browser (Juharis, 2008).

\subsection{CSS}

CSS adalah suatu cara untuk membuat format atau layout halaman web menjadi lebih menarik dan mudah dikelola (Husni,2007) CSS muncul karena sulitnya mengatur layout tampilan dokumen yang dibuat dengan HTML murni meskipun telah menggunakan berbagai kombinasi format. Untuk mempercantik tampilan sistem

\subsection{Framework CodeIgniter $(\mathrm{CI})$}

Bootstrap adalah front-end framework yang bagus dan luar biasa yang mengedapankan tampilan untuk mobiledevice (Handphone, smartphone dan lain-lain) guna mempercepat dan mempermudah pengembangan website.

Bootstrap menyediakan HTML, CSS dan Javascript siap pakai dan mudah untuk dikembangkan. Bootstrap merupakan framework untuk membangun desain web secara responsif. Artinya, tampilan web yang dibuat oleh bootstrap akan menyesuaikan ukuran layar dari browser yang kita gunakan baik di desktop, tablet ataupun mobile device. Fitur ini bisa diaktifkan ataupun dinonaktifkan sesuai dengan keinginan kita sendiri. Sehingga, kita bisa membuat web untuk tampilan desktop saja dan apabila dirender oleh mobile browser maka tampilan dari web yang kita buat tidak bisa beradaptasi sesuai layar. Dengan bootstrap kita juga bisa membangun web dinamis ataupun statis (Alatas, 2013)

\subsection{Bootstrap}

Bootstrap adalah front-end framework yang bagus dan luar biasa yang mengedapankan tampilan untuk mobiledevice (Handphone, smartphone dan lain-lain.) guna mempercepat dan mempermudah pengembangan website. Bootstrap menyediakan HTML, CSS dan Javascript siap pakai dan mudah untuk dikembangkan. Bootstrap merupakan framework untuk membangun desain web secara responsif. Artinya, tampilan web yang dibuat oleh bootstrapakan menyesuaikan ukuran layar dari browser yang kita gunakan baik di desktop, tablet ataupun mobile device. Fitur ini bisa diaktifkan ataupun dinonaktifkan sesuai dengan keinginan kita sendiri.Sehingga, kita bisa membuat web untuk tampilan desktop saja dan apabila dirender oleh mobile browser maka tampilan dari web yang kita buat tidak bisa beradaptasi sesuai layar. Dengan bootstrap kita juga bisa membangun web dinamis ataupun statis (Alatas, 2013) 


\subsection{Google Maps API}

Google Maps adalah layanan gratis yang diberikan oleh Google dan sangat popular.Google Maps adalah suatu peta dunia yang dapat kita gunakan untuk melihat suatu daerah. Dengan kata lain, Google Maps merupakan suatu peta yang dapat dilihat dengan menggunakan suatu browser. Kita dapat menambahkan fitur Google Maps dalam web yang telah kita buat atau pada blog kita yang berbayar maupun gratis sekalipun dengan Google Maps API.Google Maps APIadalah suatu library yang berbentuk JavaScript. (Kindarto, 2008).

\section{METODE PENELITIAN}

\subsection{Metode pengumpulan data}

Prosedur Pengumpulan

atau pengumpulan data Adalah data yang diperoleh langsung dari Instansi baik melalui pengamatan maupun pencatatan terhadap obyek penelitian. Meliputi :

\section{Metode Wawancara}

Wawancara merupakan suatu teknik pengumpulan data dengan jalan mengadakan komunikasi dengan sumber data. Komunikasi tersebut dilakukan dengan dialog (Tanya Jawab) secara lisan, baik langsung, maupun tidak langsung. Tanya jawab untuk mendapatkan data profil deskripsi secara singkat serta lokasi sekolah dibawah naungan balitbang agama semarang.

2. Metode Observasi

Observasi adalah pengamatan langsung para pembuat keputusan berkat lingkungan fisiknya dan pengamatan langsung suatu kegiatan yang sedang berjalan. Metode observasi yang dilakukan peneliti yaitu datang ke kantor UPT balitbang agama semarang serta mengamati dan mencatat hasil dari keputusan yang sudah disepakati.

\section{Metode Studi Literatur}

Studi literatur dilakukan untuk menambah wawasan dan tinjauan pustaka untuk pengumpulan informasi melalui buku dan jurnal.

\subsection{Metode pengembangan data}

Dalam pengembangannya metode waterfall memiliki beberapa tahapan yang runtut sebagai berikut:
Analisa Kebutuhan, adalah analisa kebutuhan sistem yang dibuat dalam bentuk yang dapat dimengerti oleh klien dan staf pengembang.

Dalam tahap ini klien atau pengguna menjelaskan segala kendala dan tujuan serta mendefinisikan apa yang diinginkan dari sistem. Setelah dokumen spesifikasi disetujui maka dokumen tersebut menjadi kontrak kerja antara klien dan pihak pengembang serta melakukan analisis keterkaitan dari halaman satu dengan halaman lainnya (link).

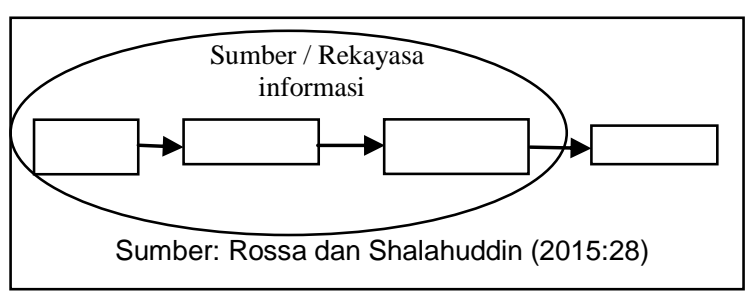

Gambar 1 Tahapan Metode Waterfall

Waterfall model adalah salah satu model pengembangan software, dimana kemajuan suatu proses dipandang sebagai terus mengalir ke bawah seperti air terjun. Merancang sistem perangkat lunak yang dibutuhkan menggunakan prinsip dari metode rekayasa perangkat lunak model waterfall. Sesuai dengan mekanisme model waterfall, terdapat tahapan perancangan perangkat lunak, yaitu:

Tahap - tahap pengembangan waterfall model adalah :

\section{a) Analisis dan kebutuhan}

Menganalisis kebutuhan yang apa aja yang diperlukan dalam pembuatan sistem informasi geografis berbasis web ini

b) Perancangan sistem dan perangkat lunak Merancang perangkat lunak sistem informasi geografis berbasis web sesuai dengan hasil dan analisis kebutuhan

c) Implementasi

Mengimplementasikan dan membuat perangkat lunak sistem informasi geografis yang telah dirancang sesuai kebutuhan sistem.

\section{d) Pengujian}

Tahap pengujian sistem informasi geografis berbasis web dan memastikan apakah sudah sesuai dengan kebutuhan perangkat lunak Setelah pengujian, perangkat lunak dapat dikirimkan ke user dikalangan balitbang agama semarang 
e) Operasi dan pemeliharaan

Mengoperasikan dan Melakukan pemeliharaan pada sistem informasi geografis berbasis web ini apabila terjadi masalah pada sistem Biasanya meningkatkan implementasi dari unit sistem, dan meningkatkan layanan sistem sebagai kebutuhan baru.

\section{f) Lingkungan Pengujian Sistem}

Pengujian sistem ini dilakukan pada lingkungan perangkat lunak dan perangkat keras. Yang digunakan pada saat pembuatan sistem
a. Perangkat Lunak Pengujian
Software yang digunakan untuk membuat Sistem Informasi Geografis
a) Sistem OS Win 7 64bit
b) Database server : MySQL
c) Web Server : Apache server localhost
d) Browser Google Chrome/Firefox
e) Text editor : Sublime text
f) Pemodelan UML : StarUML

Hardware yang digunakan untuk membuat Sistem Informasi Geografis
a) Laptop : dengan Spesifikasi
Processor INTEL CORETM I5- 3317U CPU @ 1.70ghz,
b) Graphics Intel HD 4000 Series
c) Memory 4096MB RAM.
d) Harddrive 500gb

\section{g) Black Box Testing}

Pengujian black box mengevaluasi hanya dari tampilan luarnya aja, fungsionalitas tanpa mengetahui apa sesungguhnya yang terjadi dalam proses detailnya (hanya mengetahui input dan output)

Setelah spesifikasi pengembangan telah terpenuhi, maka selanjutnya adalah pengembangan aplikasi ini ke tahap pembuatan

\section{HASIL DAN PEMBAHASAN \\ 4.1 Tampilan User Interface}

Berikut ini tampilan halaman utama sistem informasi geografis balitbang agama semarang antar muka yang sangat sederhana untuk memudahkan pengguna dalam mengakses sistem ini . Tampilan maps menggunakan Satelit seperti yang ditunjukkan pada Gambar 2.

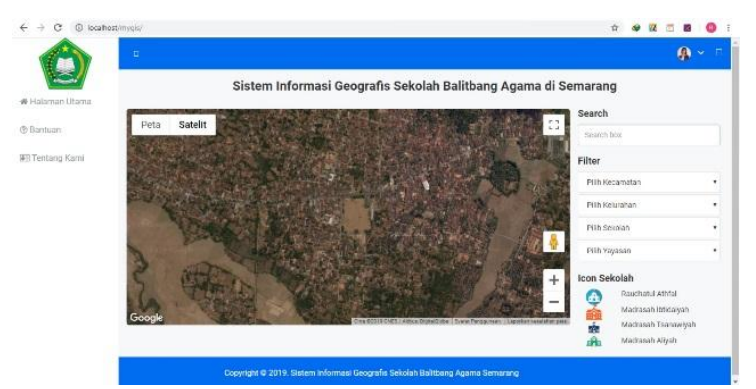

Gambar 2. Tampilan halaman utama user interface menggunakan satelit

Jika user mengakses halaman web maka akan tampil halaman seperti gambar 2, user tinggal memilih menggunakan satelit atau peta sistem tersebut telah berhasil menampilkan peta pada server google maps.

Tampilan halaman utama sistem informasi geografis balitbang agama semarang berupa tampilan maps menggunakan peta seperti yang ditunjukkan pada Gambar 3.

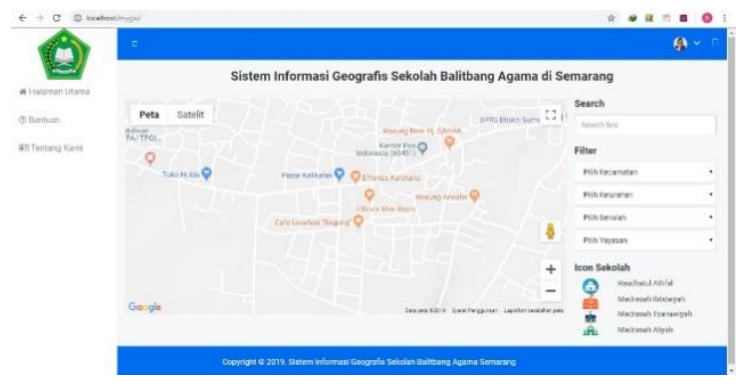

Gambar 3. Tampilan halaman utama user interface menggunakan peta

\subsection{Tampilan Halaman pencarian}

Tampilan ketika kita ingin mencari lokasi sekolah madrasah ibtidaiyah dengan cukup mengetik "MI" saja pada kolom search, maka akan tampil seperti pada Gambar 4.

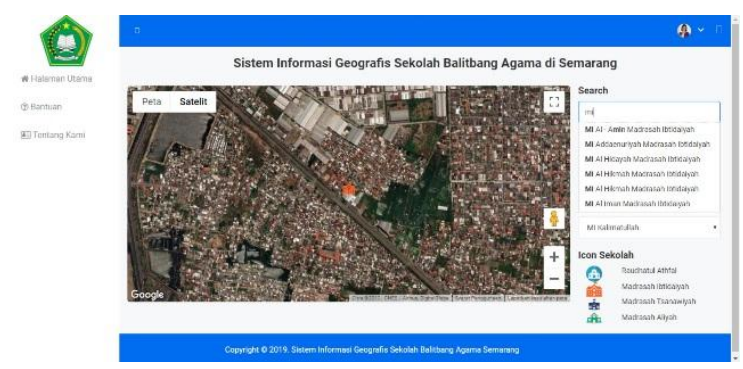

Gambar 4. Tampilan halaman search(pencarian) lokasi sekolah 
Setelah itu akan tampil titik koordinat lokasi sekolah tersebut data ini didapat dari satelit google seperti pada Gambar 5.

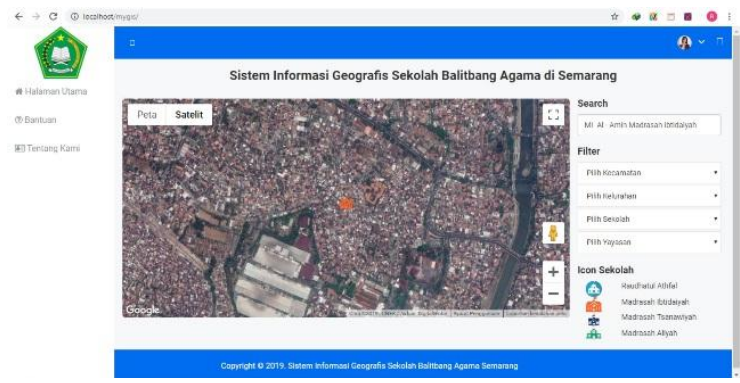

Gambar 5. Tampilan halaman setelah search(pencarian) lokasi sekolah menggunakan satelit

Sedangkan Gambar 6. menunjukkan tampilan titik koordinat lokasi sekolah menggunakan peta.

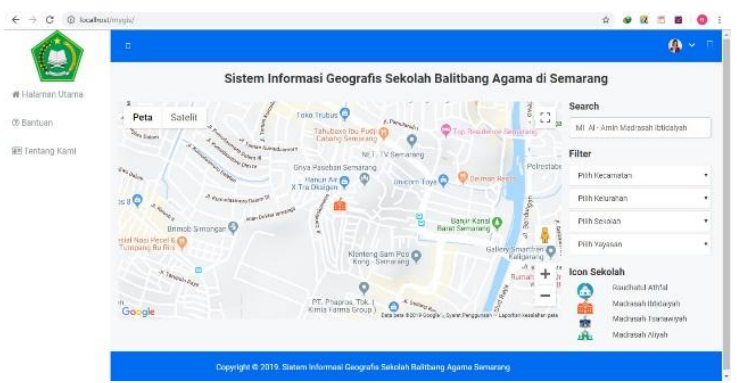

Gambar 6. Tampilan halaman setelah search(pencarian) lokasi sekolah menggunakan peta

Jika ingin mencari lokasi sekolah menggunakan filter kecamatan dan kelurahan berdasarkan lokasi sekolah tersebut, data didapat dari satelite, seperti pada Gambar 7.

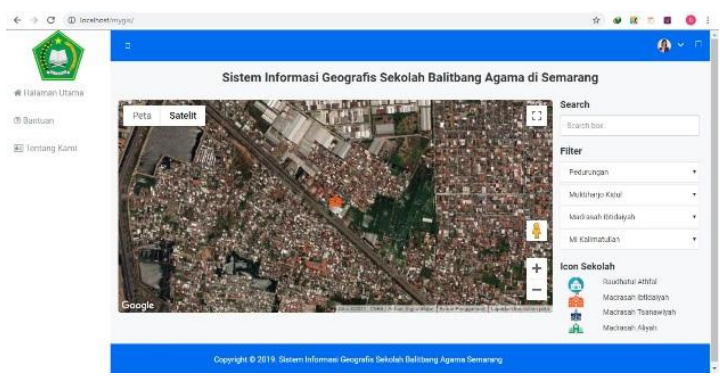

Gambar 7. Tampilan halaman search (pencarian) lokasi sekolah fitur filter menggunakan satelit
Tampilan pada Gambar 8 menunjukkan data didapat dari peta yang menggunakan filter kecamatan dan kelurahan berdasarkan lokasi sekolah tersebut.

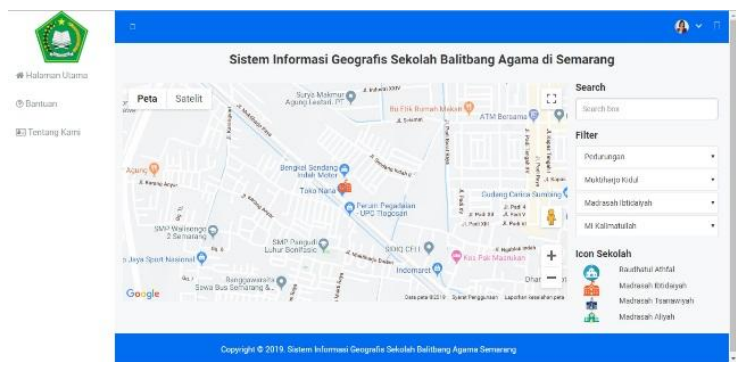

Gambar 8. Tampilan halaman search(pencarian) lokasi sekolah fitur filter menggunakan peta

Tampilan pada Gambar 9 menunjukkan halaman bantuan apabila pengguna kesulitan dalam melakukan pencarian lokasi alamat sekolah sehingga memudahkan pengguna dalam menggunakan sistem ini.

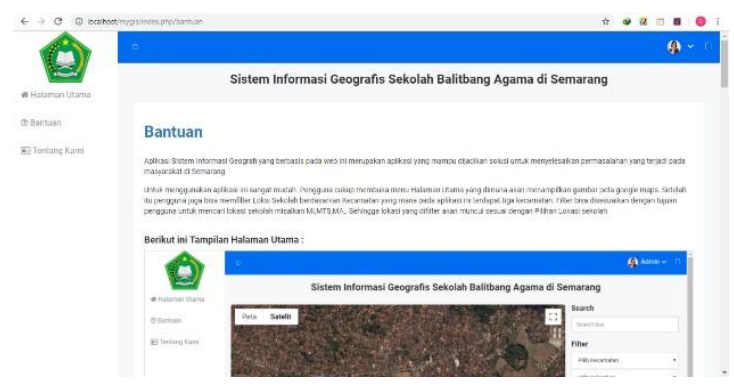

Gambar 9. Tampilan halaman Bantuan user interface

Ini merupakan tampilan halaman tentang kami, untuk menguraikan secara singkat sejarah balitbang semarang, seperti yang ditunjukkan pada Gambar 10.

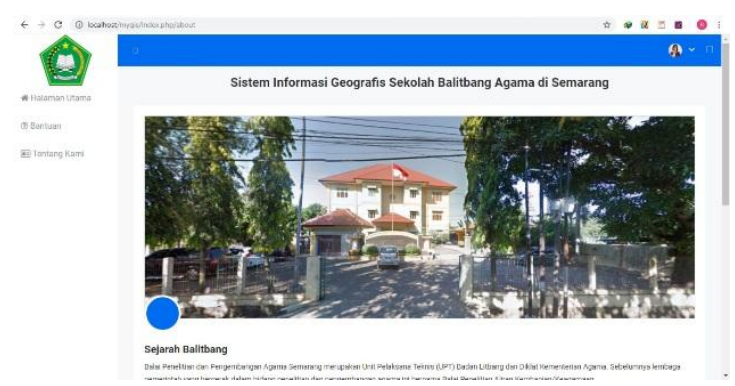

Gambar 10. Tampilan halaman Tentang Kami user interface 


\subsection{Tampilan Login}

Gambar 11 merupakan tampilan halaman menu login admin.



Gambar 11. Tampilan halaman Login user interface

\subsection{Tampilan Halaman Admin}

Setelah itu admin memasukkan username dan password maka akan tampil halaman seperti Gambar 12.

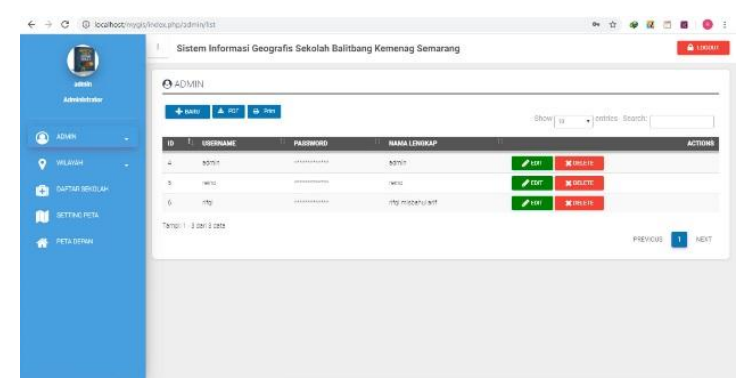

Gambar 12. Tampilan halaman admin setelah admin login

Tampilan pada Gambar 13 merupakan halaman wilayah daftar kecamatan di wilayah semarang :

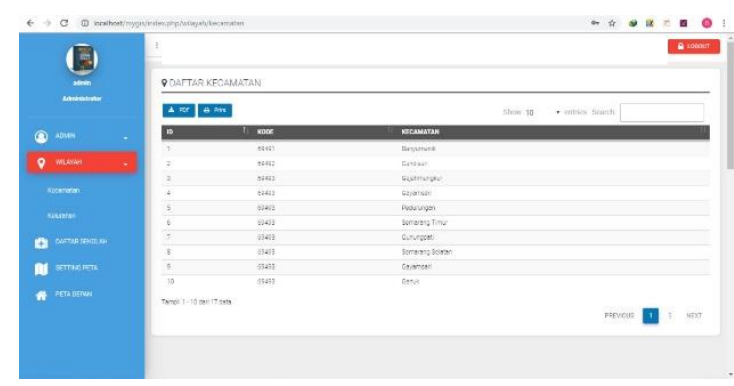

Gambar 13. Tampilan halaman wilayah user interface

\subsection{Tampilan Halaman Wilayah}

Tampilan pada Gambar 14 merupakan halaman wilayah daftar kelurahan di wilayah semarang admin tinggal memilih pada kolom pilih kecamatan.



Gambar 14. tampilan halaman wilayah pada daftar kelurahan user interface

\subsection{Tampilan Halaman daftar sekolah}

Tampilan Gambar 15 merupakan halaman daftar sekolah jika admin ingin menambahkan sekolah berdasarkan kecamatan kelurahan kecamatan dan keterangan.

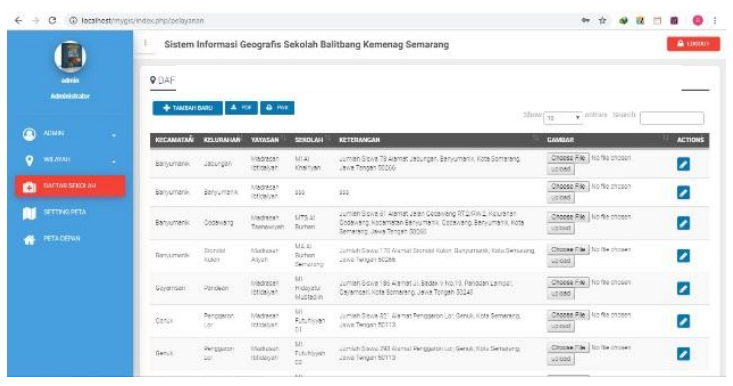

Gambar 15. Tampilan halaman daftar sekolah user interface

\subsection{Tampilan Halaman Setting Peta}

Tampilan Gambar 16 merupakan halaman setting peta, pilih lokasi sekolah berdasarkan kecamatan kelurahan dan yayasan.

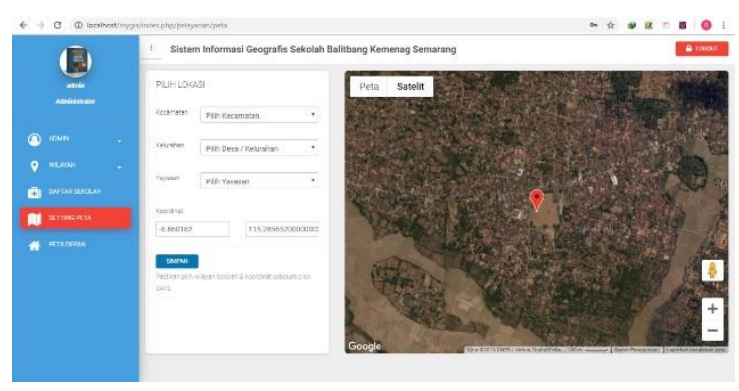

Gambar 16. Tampilan halaman setting pata user interface

\section{PENUTUP}

\subsection{Kesimpulan}

Berdasarkan hasil Penelitian ini, penulis mengambil kesimpulan :

a) Peneliti telah berhasil membuat sistem informasi geografis untuk pendataan 
sekolah pada naungan balitbang semarang, sehingga user dikalangan balitbang bisa mengakses

b) Desain yang dibuat pada WebGIS ini telah berhasil dengan simple dan user friendly sehingga mudah sekali dalam mengaksesnya Informasi yang disajikan mengenai sekolah setempat berupa titik koordinat, nama sekolah, alamat, data siswa

c) Dengan WebGis ini memungkinkan para user untuk mengetahui dan mencari sekolah mana saja yang ada di wilayah semarang yang dapat diakses dengan mudah secara online menggunakan website.

\subsection{Saran}

Adapun saran yang dapat dikemukakan adalah sebagai berikut:

Penulis juga ingin menyampaikan saran terhadap pengembang Sistem Informasi Geografis ini lebih lanjut dan perbaikan kekurangan yang ada, diantaranya :

a) Dapat dijadikan pertimbangan bagi pengguna untuk memilih sekolah-sekolah dengan adanya informasi mengenai sekolah tersebut.

b) Mengembangkan Sistem Informasi Geografis dengan memperluas cakupan wilayah yang ditampilkan, dengan cara menambah wilayah-wilayah yang ada di Kabupaten.

c) Dengan perkembangan teknologi yang sangat cepat, melengkapi layer pada peta seperti jalur jalan penghubung yang lebih detail juga akan sangat dibutuhkan karena pada peta yang sekarang masih terlihat jalan utamanya saja.

\section{DAFTAR PUSTAKA}

Alatas, H. 2013. Responsive Web Design dengan PHP dan Bootstrap, Yogyakarta : Lokomedia.

Husni. 2007. Pemrograman Database Berbasis Web. Yogyakarta: Graha Ilmu.

Irwansyah, Edy. 2013. Sistem Informasi geografis : Prinsip Dasar dan Pengembangan Aplikasi.Yogyakarta: Digibook.

Juharis. 2008. Teknologi Informasi dan Komunikasi 2. Penerbit : Yudhistira Ghalia.
Kharistiani E., Aribowo E., Sistem Informasi Geografis Pemetaan Potensi SMA/SMK Berbasis WEB, Jurnal Sarjana Teknik Informatika Vol. 1, No. 1, Juni 2013 eISSN: 23385197

Kindarto, Asdani. 2008. Asyik Berinternet dengan Beragam Layanan Google. Yogyakarta: Penerbit Andi.

Nur Rizky, Y., Nugraha, A., \& Wijaya, A. 2015. APLIKASI SISTEM INFORMASI GEOGRAFIS BERBASIS WEB UNTUK PERSEBARAN SEKOLAH MENENGAH ATAS (Studi Kasus : Kota Semarang). Jurnal Geodesi Undip, 4(1), 172-182.

Prahasta, Eddy. 2014. Sistem Informasi Geografis Konsep-Konsep Dasar (Perspektif Geodesi \& Geomatika). Bandung: Informatika.

Rosa AS dan M.Shalahuddin. 2015. Rekayasa Perangkat Lunak Terstruktur Dan Berorientasi Objek. Bandung : Informatika 